ORIGINAL ARTICLE / ARTIGO ORIGINAL

Is alcohol outlet density in the residential area associated with alcohol consumption among adolescents?

\title{
Densidade de estabelecimentos que comercializam bebidas alcoólicas na área residencial está associada ao consumo de álcool em adolescentes?
}

\author{
Bruno Guimarães Coelho de Carvalho' (iD, Amanda Cristina de Souza Andrade" (D), \\ Roseli Gomes de Andrade' (D), Larissa Loures Mendes' (D), Gustavo Velasquez-Melendez' (D), \\ César Coelho Xavier III (ID, Fernando Augusto Proiettill,IV (D), Waleska Teixeira Caiaffal (D)
}

\begin{abstract}
Objective: To investigate the association between the alcohol outlet density in residential areas and the current and lifetime alcohol consumption, adjusted for individual and family factors. Method: Information from a three-stage household stratified probabilistic cluster sampling survey (census tract, household, adult and adolescent), conducted in Belo Horizonte, Brazil ("Health in BH", 2008-2009) and data of the establishments were obtained from official sources and subsequently georeferenced. The outcome was the adolescents' report of current and lifetime alcohol consumption. The exposure variable was the alcohol outlet density, defined as the number of establishments within a 200-meter range from the adolescents' residence. The association was estimated by Poisson regression adjusted by individual and family variables. Results: In total, 601 adolescents aged 14 to 17 years were included in this study. Of these, $53.3 \%$ were males and $71.0 \%$ lived in a family with income up to five minimum wages. The prevalence of lifetime alcohol consumption was $57.0 \%(95 \% \mathrm{CI}$ $51.5-62.6)$ and the current was $11.9 \%(95 \% \mathrm{CI} 8.7-15.0)$. The multivariate analysis showed a significant association between current alcohol consumption and density of snack bars (PR $=1.13 ; 95 \% \mathrm{CI} 1.03-1.24)$, bars $(\mathrm{PR}=1.21 ; 95 \mathrm{CI} \% 1.05-1.38)$, and restaurants $(\mathrm{PR}=1.11 ; 95 \% \mathrm{CI} 1.02-1.21)$. Significant interactions between density of establishments with sex and age were found. Conclusion: Current alcohol consumption may be enhanced by the availability of some types of establishments located within a range of 200 meters from the adolescents' residence.
\end{abstract}

Keywords: Underage drinking. Alcohol-related disorders. Neighborhood. Urban health.

Universidade Federal de Minas Gerais - Belo Horizonte (MG), Brazil

"Universidade Federal de Mato Grosso - Cuiabá (MT), Brazil.

"'Faculdade da Saúde e Ecologia Humana - Vespasiano (MG), Brazil.

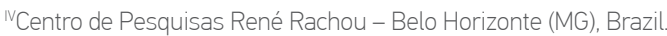

Corresponding author: Bruno Guimarães Coelho de Carvalho. Observatório de Saúde Urbana de Belo Horizonte, Faculdade de Medicina, Universidade Federal de Minas Gerais. Avenida Alfredo Balena, 190, sala 730, CEP: 30130-100, Belo Horizonte, MG, Brazil. E-mail: brunoenfermeiro01@gmail.com

Conflict of interests: nothing to declare - Financial support: Minas Gerais State Research Support Foundation (Fapemig) [APQ00975-08]; National Council for Scientific and Technological Development (CNPq) [Project number 47504/2006-0 and Productivity Scholarship (WTC)]; Ministry of Health [FNS-162/2006]; Fogarty International Training Grant - NIH [1R03TY008105-01]. 
RESUMO: Objetivos: Investigar a associação entre a densidade de estabelecimentos de venda de bebidas alcoólicas no entorno da residência dos adolescentes e a prevalência de consumo de álcool na vida e atual, ajustado por fatores individuais e familiares. Métodos: As informações provêm da pesquisa domiciliar por amostragem probabilística estratificada e por conglomerados em três estágios (setor censitário, domicílio, adulto e adolescente), realizada em Belo Horizonte, Brasil (Saúde em Beagá, 2008-9) e de fontes oficiais de estabelecimentos que comercializam bebidas alcoólicas, devidamente georreferenciados. O desfecho foi o autorrelato de consumo de álcool na vida e atual pelos adolescentes. A variável de exposição foi a densidade de estabelecimentos definida como número de locais de venda de bebida dentro do buffer de 200 metros da residência dos adolescentes. A associação foi estimada pela regressão de Poisson ajustada por fatores individuais e familiares. Resultados: Participaram 601 adolescentes de $14-17$ anos; 53,3\% eram homens e $71 \%$ tinham renda familiar até cinco salários mínimos. A prevalência de consumo de álcool na vida foi de $57,0 \%$ (intervalo de confiança de $95 \%$ - IC $95 \%$ 51,5 - 62,6) e o atual de 11,9\% (IC95\% 8,7 - 15,0). Na análise multivariada, verificou-se associação significativa entre o consumo atual de bebidas alcoólicas e a densidade de lanchonetes (razão de prevalência - RP = 1,13; IC95\% 1,03-1,24), bares $(\mathrm{RP}=1,21$; IC95\% 1,05-1,38) e restaurantes $(\mathrm{RP}=1,11$; IC95\% 1,02-1,21). Interações significativas entre densidade de estabelecimentos com sexo e idade foram encontradas. Conclusão: O consumo atual de álcool pode ser potencializado pela presença de alguns tipos de estabelecimentos localizados no buffer de 200 metros da residência dos adolescentes.

Palavras-chave: Consumo de álcool por menores. Transtornos relacionados ao uso de álcool. Vizinhança. Saúde urbana.

\section{INTRODUCTION}

Alcohol is considered a psychoactive substance and its abuse can be identified as one of the main risk factors for populational health. In 2016, it was the cause of $5.3 \%$ of all deaths worldwide, overcoming diseases such as tuberculosis, human immunodeficiency virus (HIV)/acquired immunodeficiency syndrome (AIDS), and diabetes ${ }^{1}$. Policies aimed at regulating alcohol consumption have improved globally, but still do not provide populations with effective protection against the damage caused by alcohol ${ }^{1}$.

About 2.3 billion people in the world currently drink alcohol. In the case of adolescents - individuals aged 10 to 19 years $^{2}$ - it can reach $26.5 \%$ among the aged 15 to 19 years ${ }^{1}$. Despite prohibitive laws, adolescents find little difficulty in accessing this substance ${ }^{3}$. Facilitators are often related to individual and family characteristics ${ }^{4,5}$, as well as to the characteristics of the environment in which they operate ${ }^{6,7}$.

Access to drinking occurs primarily through the influence of parents, in the case of young adolescents ${ }^{8}$. As they get older, the neighborhood assumes this role because there are commercial establishments selling drinks in their housing are $\mathrm{a}^{8-10}$.

The physical availability of places for the sale of alcoholic beverages has the potential to influence the demand for alcohol consumption, although international studies, investigating the association between alcohol outlet density in the neighborhood and alcohol consumption by adolescents, have reported divergent results of positive effects ${ }^{7,11-14}$ and even no association ${ }^{15,16}$. 
In Brazil, to our knowledge, there is still a gap in studies that explore the availability of commercial establishments selling alcoholic beverages and consumption by the young population ${ }^{3,9,10}$, despite the strong presence of such places open at any time of the day or night ${ }^{9,10}$. The reduction of such establishments can be considered a highly effective strategy to reduce alcohol consumption and related problems ${ }^{1,9}$. Thus, the fragile legislation and the apparent ease in access to drink, associated with a relative absence of studies in the Brazilian context, can directly affect the planning and evaluation of health campaigns and policies.

Therefore, the present study aimed to investigate the association between the alcohol outlet density in the vicinity of adolescents' residential area and the prevalence of lifetime and current alcohol consumption, adjusted for individual and family factors.

\section{METHODS}

\section{TYPE OF STUDY AND SAMPLE DESIGN}

The data come from the study "Saúde em Beagá" ("Health in BH"), a home-based health survey conducted by the Belo Horizonte Observatory for Urban Health and the Medical School of Universidade Federal de Minas Gerais (OSUBH/FM/UFMG), August 2008 to February 2009.

We adopted a probabilistic sample, stratified by the index of vulnerability to health and by clusters in three stages (census tract, household, adult, and adolescent when there was at least one). In each household, an adult was randomly selected and invited to participate in the research. If there was an adolescent in the house, he/she would be also invited to participate. In total, 4,408 interviews were carried out with adults and 1,042 interviews with adolescents aged 11 to 17 years old; 434 aged 11 to 13 years old; and 608 aged 14 to 17 years old. More details about the survey are to be found in previous works ${ }^{17-19}$.

For data collection, two instruments were used, one for adults and one for adolescents. The adult questionnaire had questions addressing the socioeconomic domain, social determinants of health, health, habits, and behaviors. The one aimed at adolescents had questions fitting each age group. For all age groups, aspects related to access to material goods, education, relationships with parents and friends, health-related habits and behaviors, and subjective well-being were addressed. Only for the 14-17 age group were added questions related to alcohol consumption. That being said, for this study, we will consider only the sample with participants in this age group ${ }^{20}$.

\section{OUTCOME VARIABLES}

As outcome variables, the following questions were considered: "Have you ever had alcohol? (yes; no)", to determine lifetime consumption; and "Do you currently have alcohol? (yes; no)", to assess current consumption. 


\section{EXPOSURE VARIABLES}

The alcohol outlet density, such as supermarkets, mini-markets, bakeries, liquor stores, cafeterias, bars, and restaurants, was defined as the number of places in a 200-meter range surrounding the interviewee's residence. To calculate the number of establishments in this range, the geographic coordinates of the residence of each adolescent and of the establishments were plotted in a shape using the ArcGIS 10.3 software. Then, around each point representing a residence, circular buffers of the Euclidean type measuring 200 meters in radius were drawn. The 200-meter range was primarily chosen because the value was more recurrent, repeated in two different studies ${ }^{12,15}$; secondly, because a study ${ }^{21}$ using data also from the study "Saúde em Beagá" identified that for $57.8 \%$ of the participants, "neighborhood" was limited to the nearby houses until the end of the block. Within each buffer, establishments were counted by type.

The data referring to establishments comply with the National Classification of Economic Activities (CNAE) standards and were made available in 2011 by the Secretariat of State Revenue, by the Superintendence of Collection and Tax Information and by the Directorate of Economic and Tax Information of Minas Gerais. The information of the establishments was georeferenced based on postal codes, in which the addresses were crossed with the latitude and longitude positioning coordinates obtained from the global positioning system $(\mathrm{GPS})^{22}$. The coordinates were obtained using the centroid of the street that corresponded to the postal code of each establishment.

\section{ADJUSTMENT VARIABLES}

The adolescents' individual variables were: age (years); sex (female; male); bullying ("Have you ever suffered any kind of intimidation, offense, aggression or persecution with insistence, making you feel humiliated or scared?"; yes, no); participation in fights ("In the last year, did you get into any fights where someone was hurt?"; yes, no); difficulty interacting with colleagues ("Do you feel awkward or uncomfortable in situations such as parties or groups?"; yes, no); nice and helpful friends ("Do you find your colleagues or friends nice and helpful?"; yes, no); cigarette use in life ("Have you ever smoked cigarettes?"; yes, no); current cigarette use ("Do you smoke?"; yes, no); studying in 2008 ("Are you studying this year, in 2008?”; yes, no); failed school year (no/not studying, yes; variable obtained from the comparison between the grade declared by the interviewee and that expected for their age); type of school ("About the school you attend; not currently studying, public school, private school); satisfaction with school life ("About the school you attend, you": like it a lot, like it a little, do not like it/not currently studying); participation in any organization ("Do you participate in any type of organization or groups (church; volunteer/community work; school guild; student bodies; others)?”; yes, no). 
Family variables were: family fights/arguments ("Usually, there are fights/arguments within families. Comparing your family with others you know, what would you say about your family?"; there is no fight, little fight, we fight a lot); feeling loved ("My parents or those who raised me, make me feel loved and cared for:"; yes, no); parents at home ("Who are the people who live with you?"; mother and father, father, mother, others); talk time with parents ("In general, how often does your father or mother or who raises you spend time talking to you (in person, on the phone or on the internet)?"; never, rarely, sometimes, always); education of the head of the family ("Up to which grade did the head of this household attend school?" the answer options were converted into years of study: 0 to 4,5 to 8,9 to 11,12 years or more); adult who drinks ("Do you consume alcohol?"; yes, no); family income ("Counting all the money that all residents of this house receive, the total is:"; $<2,2$ to 3,3 to 5,5 to $10, \geq 10$ minimum wages).

\section{DATA ANALYSIS}

Initially, prevalence and 95\% confidence intervals (95\%CI) of current and lifetime alcohol consumption among adolescents was estimated. Then, using univariate analysis with estimates of prevalence ratios (PR) and calculation of the respective confidence intervals, we verified which of the individual and family explanatory variables and alcohol outlet density were associated with alcohol consumption. Variables with a p-value less than or equal to 0.20 were included in the multivariate model.

In the multivariate model, sex and age variables were used as adjustment factors. The hierarchical entry of the variables in blocks was adopted, with adjustment factors first, followed by individual and family variables. For each variable included, we checked whether the association with alcohol consumption was significant. If not, it was excluded from the model. The final model included the density of establishments. Because of the collinearity between the types of establishments, we decided to adjust a separate multivariate model for each density of establishment. Poisson regression with robust variance was used in all analyses. Analyses were made separately for lifetime and current consumption.

Finally, the possible multiplicative interactions between the variables sex, age, and density for each type of establishment were evaluated. The PR of alcohol consumption was estimated, according to the variables with significant interaction, considering the adjustment for the other factors included in this analysis. The results of the interactions were presented in graphs.

For the interpretation of the results, we considered a significance level of $5 \%$. The analyses were performed using the Stata software, version 12.0 (StataCorp LP, College Station, United States). The complex design of the sample and the weighting factors were incorporated into the analysis.

The study was approved by the UFMG Ethics and Research Committee (ETIC Process $\left.N^{\circ} .253 / 06\right)$. Participants were informed about confidentiality and all characteristics of the study. An informed consent form was signed by the adults interviewed, by a parent or guardian in the case of adolescents, as well as participants from the age group of 14 to 17 years. 


\section{RESULTS}

Of the 608 adolescents, seven were excluded because of a lack of information. Thus, the sample of this study was composed of 601 adolescents, being $53.3 \%$ males; $55.4 \%$ aged 14 to 15 years, and $71 \%$ living in households whose family income was up to five minimum wages. With regard to alcohol consumption, 57.0\% (95\%CI 51.5 - 62.6) reported having consumed it once in their lives and $11.9 \%(95 \% \mathrm{CI} 8.7-15.0)$ reported current consumption.

The variables statistically associated with alcohol consumption in life were participation in fights; not having difficulties interacting with colleagues; lifetime and current smoking; less satisfaction with school life; family fights/arguments; less talk time with parents, and presence of an adult who drinks in the family. For current consumption, the following information stands out: participation in fights; lifetime and current smoking; failing in school; school network; participation in social organizations, and less talk time with parents (Tables 1 and 2).

Regarding the alcohol outlet density around the adolescents' homes, there was a higher frequency of mini-markets (60.34\%), followed by bars $(50.09 \%)$ and snack bars $(46.41 \%)$. The univariate analysis found a significant association between current alcohol consumption and snack bar density (PR $=1.18 ; 95 \% \mathrm{CI} 1.07-1.31)$, bars $(\mathrm{PR}=1.35 ; 95 \% \mathrm{CI} 1.13-$ $1.62)$, and restaurant $(\mathrm{PR}=1.16 ; 95 \% \mathrm{CI} 1.05-1.28)$. For lifetime consumption, no association with any type of establishment was observed (Table 3 ).

In the multivariate analysis (Table 4), the alcohol outlet density did not show a significant association with alcohol consumption in life, even if adjusted for the variables age, sex, family income, participation in fights, difficulty interacting with colleagues, satisfaction with school life, family fights/arguments, talk time with parents, and adults who drink in the family.

Current consumption (Table 4) remained positively associated with the density of snack bars $(\mathrm{PR}=1.13 ; 95 \% \mathrm{CI} 1.03-1.24)$, bars $(\mathrm{PR}=1.21 ; 95 \% \mathrm{CI} 1.05-1.38)$, and restaurants $(\mathrm{PR}=1.11 ; 95 \% \mathrm{CI} 1.02-1.21)$, even after adjusting for age, sex, family income, participation in an organization, and talk time with parents.

For lifetime and current alcohol consumption, after adjusting all variables considered in the study, we found interactions between:

- the alcohol outlet density (snack bars, bars, and restaurants) and sex;

- the alcohol outlet density and age.

The prevalence of consumption was higher among female adolescents living in neighborhoods with a higher density of bars and snack bars for current consumption, and only the density of bars for lifetime consumption. Among male adolescents, consumption was higher in those living in neighborhoods with a higher density of restaurants. There was an increasing gradient in the prevalence of current and lifetime consumption with increasing age and density of establishments in the neighborhood, except for the interaction between age and restaurant density for lifetime consumption (Figure 1). 
Table 1. Prevalence and prevalence ratio of lifetime and current alcohol consumption according to individual variables. Belo Horizonte, 2008-2009.

\begin{tabular}{|c|c|c|c|c|c|}
\hline \multirow{2}{*}{ Variables } & \multirow{2}{*}{ Total } & \multicolumn{2}{|r|}{ Lifetime } & \multicolumn{2}{|r|}{ Current } \\
\hline & & $\% *$ & PR $(95 \% \mathrm{Cl})$ & $\% *$ & PR $(95 \% \mathrm{Cl})$ \\
\hline \multicolumn{6}{|l|}{ Age } \\
\hline 14 & 27.86 & 35.51 & 1.0 & 2.87 & 1.0 \\
\hline 15 & 27.57 & 60.00 & $1.68(1.25-2.28)$ & 7.81 & $2.71(0.89-8.28)$ \\
\hline 16 & 21.33 & 65.80 & $1.85(1.32-2.59)$ & 14.69 & $5.11(1.72-15.17)$ \\
\hline 17 & 23.24 & 71.40 & $2.01(1.54-2.62)$ & 24.86 & $8.65(3.26-22.91)$ \\
\hline \multicolumn{6}{|l|}{ Sex } \\
\hline Male & 46.49 & 58.06 & 1.0 & 10.76 & 1.0 \\
\hline Female & 53.51 & 56.19 & $1.03(0.85-1.24)$ & 12.83 & $0.83(0.51-1.36)$ \\
\hline \multicolumn{6}{|l|}{ Bullying } \\
\hline No & 73.77 & 54.30 & 1.0 & 10.40 & 1.0 \\
\hline Yes & 26.23 & 64.46 & $1.18(0.99-1.40)$ & 16.21 & $1.55(0.92-2.62)$ \\
\hline \multicolumn{6}{|c|}{ Participation in fights } \\
\hline No & 85.45 & 52.98 & 1.0 & 10.35 & 1.0 \\
\hline Yes & 14.55 & 82.11 & $1.54(1.30-1.84)$ & 21.08 & $2.03(1.14-3.61)$ \\
\hline \multicolumn{6}{|c|}{ Difficulty interacting with friends } \\
\hline No & 75.90 & 61.66 & $1.41(1.10-1.81)$ & 12.44 & $1.15(0.58-2.30)$ \\
\hline Yes & 24.10 & 53.52 & 1.0 & 10.73 & 1.0 \\
\hline \multicolumn{6}{|c|}{ Nice/reliable friends } \\
\hline No & 5.71 & 54.95 & 1.0 & 6.35 & 1.0 \\
\hline Yes & 94.29 & 58.04 & $1.05(0.70-1.58)$ & 12.78 & $2.00(0.55-7.22)$ \\
\hline \multicolumn{6}{|c|}{ Lifetime smoking } \\
\hline No & 84.91 & 50.36 & 1.0 & 8.00 & 1.0 \\
\hline Yes & 15.09 & 94.78 & $1.88(1.64-2.15)$ & 33.61 & $4.20(2.66-6.61)$ \\
\hline \multicolumn{6}{|c|}{ Current smoking } \\
\hline No & 96.62 & 55.78 & 1.0 & 9.80 & 1.0 \\
\hline Yes & 3.38 & 93.83 & $1.68(1.45-1.93)$ & 70.73 & $7.21(4.59-11.31)$ \\
\hline \multicolumn{6}{|c|}{ Student in 2008} \\
\hline No & 7.00 & 69.46 & $1.24(0.98-1.55)$ & 16.85 & $1.46(0.69-3.10)$ \\
\hline Yes & 93.00 & 56.13 & 1.0 & 11.49 & 1.0 \\
\hline
\end{tabular}


Table 1. Continuation.

\begin{tabular}{|c|c|c|c|c|c|}
\hline \multirow{2}{*}{ Variables } & \multirow{2}{*}{ Total } & \multicolumn{2}{|r|}{ Lifetime } & \multicolumn{2}{|r|}{ Current } \\
\hline & & $\% *$ & PR $(95 \% \mathrm{Cl})$ & $\% *$ & PR $(95 \% \mathrm{Cl})$ \\
\hline \multicolumn{6}{|l|}{ Failed school } \\
\hline No/not a student & 67.34 & 60.51 & $1.21(0.98-1.50)$ & 15.52 & $3.07(1.53-6.13)$ \\
\hline Yes & 32.66 & 49.72 & 1.0 & 4.97 & 1.0 \\
\hline \multicolumn{6}{|l|}{ School } \\
\hline Public & 77.08 & 54.37 & 1.0 & 8.76 & 1.0 \\
\hline Private & 15.91 & 65.04 & $1.19(0.96-1.48)$ & 24.77 & $2.82(1.60-4.97)$ \\
\hline Not enrolled in one & 7.01 & 69.46 & $1.27(1.01-1.61)$ & 16.85 & $1.92(0.85-4.30)$ \\
\hline \multicolumn{6}{|c|}{ Satisfaction with school life } \\
\hline Really likes & 46 & 52.50 & 1.0 & 11.23 & 1.0 \\
\hline Likes & 32.94 & 57.36 & $1.09(0.87-1.30)$ & 11.64 & $1.03(0.55-1.92)$ \\
\hline $\begin{array}{l}\text { Doesn't like/Not a } \\
\text { student }\end{array}$ & 21.06 & 66.62 & $1.26(1.02-1.56)$ & 13.74 & $1.22(0.65-2.27)$ \\
\hline \multicolumn{6}{|c|}{ Participation in organizations } \\
\hline No & 31.77 & 59.72 & $1.07(0.87-1.30)$ & 18.06 & $1.98(1.19-3.30)$ \\
\hline Yes & 68.23 & 55.78 & 1.0 & 9.09 & 1.0 \\
\hline
\end{tabular}

*Prevalence; PR: prevalence ratio; $95 \% \mathrm{Cl}$ : 95\% confidence interval.

Although smoking had a strong association with alcohol consumption, it was not included in the multivariate model, as there was a co-occurrence of these two behaviors among adolescents. Among adolescents who reported smoking at some time in their lives, $96 \%$ reported alcohol consumption in their lifetime and $33.61 \%$ current consumption. It was verified, through univariate analysis, that the alcohol outlet density would also be associated with smoking, however, there was no significant association between the variables lifetime smoking and density of establishments. Because of the low prevalence of current smoking, we decided not to use this variable in subsequent analyses.

\section{DISCUSSION}

More than half of the adolescents reported having consumed alcohol in their lifetime. About $10 \%$ reported recent consumption associated with the alcohol outlet density around their homes, such as snack bars, bars, and restaurants, regardless of individual and family characteristics. In addition, increasing prevalence of consumption was observed with age and with the density of establishments in the neighborhood, as well as according to the sex of the adolescent and type 
Table 2. Prevalence and prevalence ratio of lifetime and current alcohol consumption according to family variables. Belo Horizonte, 2008-2009.

\begin{tabular}{|c|c|c|c|c|c|}
\hline \multirow{2}{*}{ Variables } & \multirow{2}{*}{$\begin{array}{c}\text { Total } \\
\text { (\%) }\end{array}$} & \multicolumn{2}{|r|}{ Lifetime } & \multicolumn{2}{|r|}{ Current } \\
\hline & & $\%^{*}$ & PR $(95 \% \mathrm{Cl})$ & $\% *$ & PR $(95 \% \mathrm{Cl})$ \\
\hline \multicolumn{6}{|c|}{ Family fights/arguments } \\
\hline No fights & 26.76 & 46.14 & 1.0 & 7.74 & 1.0 \\
\hline Few fights & 60.45 & 59.05 & $1.27(0.99-1.63)$ & 12.66 & $1.63(0.77-3.46)$ \\
\hline Many fights & 12.80 & 72.71 & $1.57(1.19-2.07)$ & 17.18 & $2.21(0.98-4.97)$ \\
\hline \multicolumn{6}{|l|}{ Feeling of being loved } \\
\hline No & 3.27 & 62.98 & $1.10(0.68-1.76)$ & 17.47 & $1.50(0.42-5.34)$ \\
\hline Yes & 96.73 & 57.15 & 1.0 & 11.61 & 1.0 \\
\hline \multicolumn{6}{|l|}{ Parents in household } \\
\hline Mother and father & 63.03 & 53.72 & 1.0 & 11.52 & 1.0 \\
\hline Father & 4.68 & 49.52 & $0.92(0.54-1.55)$ & 4.24 & $0.36(0.04-2.86)$ \\
\hline Mother & 23.9 & 63.16 & $1.17(0.98-1.40)$ & 14.11 & $1.22(0.70-2.13)$ \\
\hline Others & 8.39 & 69.00 & $1.28(0.96-1.71)$ & 12.28 & $1.06(0.42-2.67)$ \\
\hline \multicolumn{6}{|l|}{ Talk time with parents } \\
\hline Never & 5.99 & 61.81 & $1.17(0.77-1.77)$ & 12.02 & $1.25(0.32-4.83)$ \\
\hline Rarely & 9.33 & 47.13 & $0.89(0.58-1.37)$ & 6.91 & $0.71(0.21-2.44)$ \\
\hline Sometimes & 24.94 & 67.02 & $1.27(1.08-1.49)$ & 17.59 & $1.82(1.03-3.22)$ \\
\hline Always & 54.73 & 52.61 & 1.0 & 9.61 & 1.0 \\
\hline \multicolumn{6}{|c|}{ Schooling of the head of the family (years) } \\
\hline $0-4$ & 27.89 & 64.78 & $1.08(0.82-1.42)$ & 9.91 & $0.48(0.21-1.05)$ \\
\hline $5-8$ & 27.88 & 48.35 & $0.81(0.58-1.12)$ & 12.6 & $0.61(0.28-1.31)$ \\
\hline $9-11$ & 30.02 & 56.79 & $0.95(0.72-1.25)$ & 9.47 & $0.45(0.21-0.98)$ \\
\hline 12 or more & 14.22 & 59.69 & 1.0 & 20.65 & 1.0 \\
\hline \multicolumn{6}{|c|}{ Adult who drinks in the family } \\
\hline No & 55.63 & 51.18 & 1.0 & 9.27 & 1.0 \\
\hline Yes & 44.37 & 64.44 & $1.25(1.05-1.50)$ & 15.12 & $1.63(0.95-2.78)$ \\
\hline \multicolumn{6}{|l|}{ Family income } \\
\hline$<2 \mathrm{mw}$ & 25.89 & 55.11 & 1.0 & 5.22 & 1.0 \\
\hline $2-3 \mathrm{mw}$ & 24.53 & 46.79 & $0.84(0.62-1.14)$ & 9.21 & $1.76(0.65-4.70)$ \\
\hline $3-5 \mathrm{mw}$ & 21.29 & 60.40 & $1.09(0.62-1.41)$ & 10.71 & $2.04(0.77-5.41)$ \\
\hline $5-10 \mathrm{mw}$ & 16.46 & 60.97 & $1.10(0.79-1.53)$ & 17.57 & $3.35(1.34-8.36)$ \\
\hline$\geq 10 \mathrm{mw}$ & 11.83 & 72.75 & $1.32(1.02-1.70)$ & 27.62 & $5.28(2.17-12.82)$ \\
\hline
\end{tabular}

*Prevalence; PR: prevalence ratio; 95\% Cl: 95\% confidence interval; mw: minimum wage. 
of establishment in the surroundings. While consumption was more prevalent among female adolescents in neighborhoods with a higher density of bars and snack bars, among males, consumption was higher among those living in neighborhoods with a higher density of restaurants.

Besides individual and family factors associated with alcohol consumption and being widely discussed in the literature, studies indicate that, as alcohol becomes less accessible,

Table 3. Density of establishments by type according to lifetime and current alcohol consumption. Belo Horizonte, 2008-2009.

\begin{tabular}{|c|c|c|c|c|c|c|}
\hline \multirow{3}{*}{ Density } & \multicolumn{3}{|c|}{ Lifetime } & \multicolumn{3}{|c|}{ Current } \\
\hline & Yes & No & \multirow{2}{*}{ PR $(95 \% \mathrm{Cl})$} & Yes & No & \multirow{2}{*}{ PR (95\% Cl) } \\
\hline & Mean (SD) & Mean (SD) & & Mean (SD) & Mean (SD) & \\
\hline Supermarkets & $0.08(0.33)$ & $0.12(0.42)$ & $0.86(0.62-1.19)$ & $0.12(0.42)$ & $0.09(0.36)$ & $1.14(0.64-2.02)$ \\
\hline Mini-markets & $1.16(1.28)$ & $1.00(1.15)$ & $1.04(0.97-1.12)$ & $1.25(1.24)$ & $1.07(1.22)$ & $1.10(0.90-1.33)$ \\
\hline Bakeries & $0.35(0.63)$ & $0.40(0.60)$ & $0.94(0.81-1.10)$ & $0.26(0.53)$ & $0.39(0.63)$ & $0.70(0.41-1.17)$ \\
\hline $\begin{array}{l}\text { Alcohol- } \\
\text { selling stores }\end{array}$ & $0.49(0.77)$ & $0.47(0.65)$ & $1.01(0.90-1.14)$ & $0.60(0.83)$ & $0.46(0.70)$ & $1.23(0.90-1.66)$ \\
\hline Snack bars & $1.06(1.60)$ & $0.80(1.22)$ & $1.05(0.99-1.09)$ & $1.48(2.05)$ & $0.88(1.34)$ & $1.18(1.07-1.31)$ \\
\hline Bars & $0.88(1.15)$ & $0.69(0.92)$ & $1.07(0.99-1.14)$ & $1.28(1.48)$ & $0.74(0.98)$ & $1.35(1.13-1.62)$ \\
\hline Restaurants & $0.93(1.66)$ & $0.68(1.12)$ & $1.04(0.98-1.10)$ & $1.30(1.85)$ & $0.76(1.38)$ & $1.16(1.05-1.28)$ \\
\hline
\end{tabular}

SD: standard deviation; PR: prevalence ratio; 95\% Cl: 95\% confidence interval.

Table 4. Multivariate analysis for lifetime and current alcohol consumption. Belo Horizonte, 2008-2009.

\begin{tabular}{l|c|c|c}
\multirow{2}{*}{ Density } & Model 1 & Model 2 & Model 3 \\
\cline { 2 - 4 } & PR $(95 \% \mathrm{Cl})$ & PR $(95 \% \mathrm{Cl})$ & PR $(95 \% \mathrm{Cl})$ \\
\hline Lifetime consumption & \multicolumn{2}{|c}{-} \\
\hline Snack bars & $1.02(0.98-1.07)^{*}$ & - & - \\
\hline Bars & - & $1.04(0.98-1.10)^{*}$ & $1.03(0.97-1.08)^{*}$ \\
\hline Restaurants & - & - & - \\
\hline Current consumption & $1.13(1.03-1.24)^{\star *}$ & - & - \\
\hline Snack bars & - & $1.21(1.05-1.38)^{* *}$ & \\
\hline Bars & - & - & $1.11(1.02-1.21)^{* *}$
\end{tabular}

PR: prevalence ratio; 95\% $\mathrm{Cl}: 95 \%$ confidence interval; *adjusted for age, sex, family income, participation in fights, difficulty interacting with colleagues, satisfaction with school life, family fights/arguments, talk time with parents, and adult who drinks in the family; ${ }^{* *}$ adjusted for age, sex, family income, participation in an organization, and talk time with parents. 
consumption and related problems decrease ${ }^{1,9}$. The World Health Organization (WHO) highlights several obstacles of regulatory, political, and commercial origin to reduce alcohol consumption among adolescents ${ }^{1}$. One of the most effective policies would be to control availability - regulation of places, times, and situations where the selling of alcoholic beverages is allowed ${ }^{1,23}$. To achieve this goal, it is important to determine what those locations are.

As in this study, establishments in which consumption occurs on the spot are associated with an increase in recent alcohol consumption ${ }^{11,12,14}$, notably in urban environment ${ }^{11}$ and in cases where the establishment is closer to the adolescent's residence ${ }^{14}$. Even when this association was not identified, the presence of the establishment increased the adolescents' perception of the availability of alcohol, which is considered a predictor of consumption in the future ${ }^{16}$.

Our study showed the density of snack bars, bars, and restaurants was associated with the current alcohol consumption, and, therefore, such establishments should be targeted by public policy actions related to inspection and functioning control. However, a high proportion of alcohol is acquired in places with lower prices and destined for external consumption, which would limit the impact of such strategies ${ }^{23}$. In our study, places with the potential to offer lower prices, such as supermarkets and liquor stores, were uncommon in the neighborhoods analyzed when compared to bars and snack bars.

Being an older teenager and the increased density of establishments were positively associated with lifetime and current alcohol consumption. This behavior would be explained by the proximity of the final phase of adolescence with adult life ${ }^{24}$. Thus, it is important to encourage discussions regarding the increase of legal age for alcohol consumption ${ }^{23}$ along with measures to raise awareness and inspection by traders, since the influence of commercial interests goes against effective alcohol control policies ${ }^{1}$.
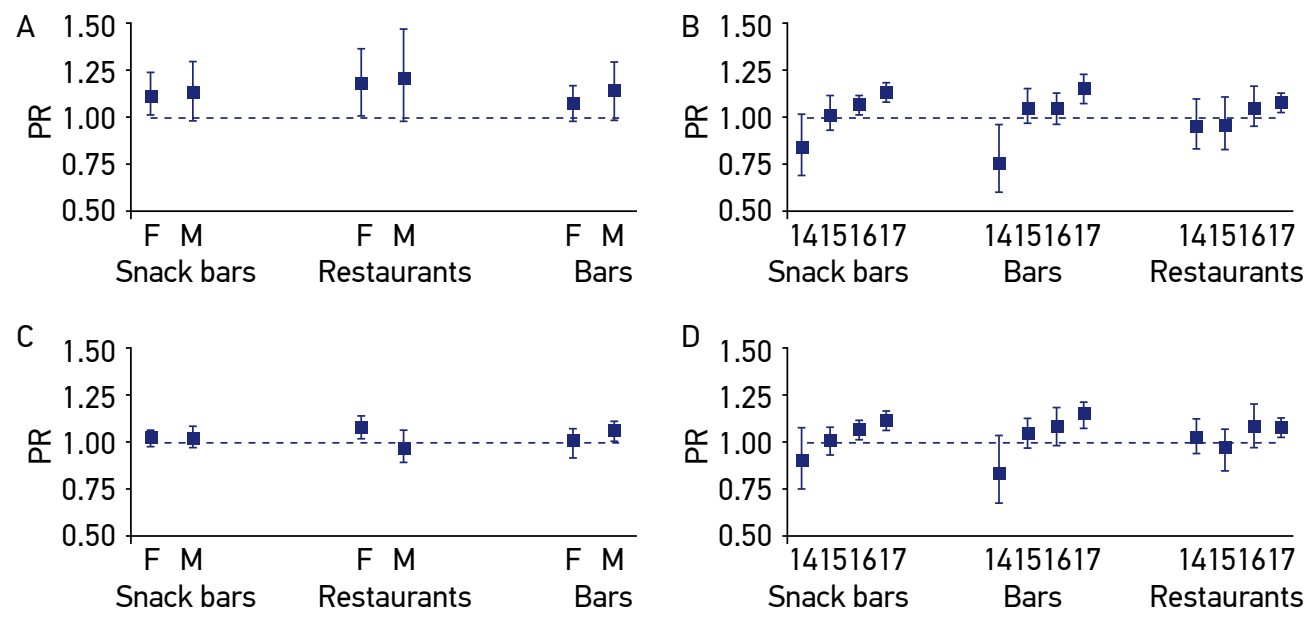

PR: prevalence ratio; F: female; M: male.

Figure 1. Interaction between the density of establishments by type and sex (A) and age (B) for current consumption; interaction between the density of establishments by type and sex $(C)$ and age (D) for lifetime consumption. Belo Horizonte, 2008-2009. 
In the present study, there was no significant association between sex and lifetime and current alcohol consumption, however, female sex presented a significant interaction with the density of establishments, with a higher prevalence of lifetime and current alcohol consumption with an increase in the density of bars and restaurants in their residence surroundings. Some studies ${ }^{25,26}$ report that female adolescents drink more regularly and start drinking later. Other works ${ }^{27,28}$ suggest that the male sex has a higher lifetime/current consumption, and in some cases, males' propensity to start alcohol use was 30\% higher compared to the female sex ${ }^{29}$. The search for virility, the feeling of self-assertion, the desire to win the respect of a group ${ }^{28}$, and freedom granted by parents ${ }^{30}$ would be justifications for the greater consumption among male adolescents.

Alcohol consumption by adolescents in association with other drugs is common, including tobacco, considered the most impacting factor when it comes to this behavior ${ }^{31}$. Data showed that $99.7 \%$ of young people who smoked daily had tried alcoholic beverages ${ }^{32}$, a standard also observed in our study. Although no independent association was found between the density of establishments and smoking ${ }^{33}$, this is a topic that needs further investigation and that requires policies, strategies, and interventions due to its direct and indirect importance to public health as a promoter of alcohol consumption, according to some studies ${ }^{1}$.

This study had some limitations, not only because of its cross-sectional design, which does not allow a causal relationship between the exposure variable and the outcome, but the questions used to measure alcohol consumption do not clearly determine the period to which recent consumption refers. Another issue is the exposure factor, since the drawing of circular buffers may encompass uninhabited areas or areas along which adolescents do not move effectively. Considering the exposition based on patterns of displacement through the road network of streets and sidewalks can be of greater precision ${ }^{34}$. The individual data in this study refer only to two health districts in Belo Horizonte and were collected in 20082009 , so we suggest caution when extrapolating the results. The base of commercial establishments is secondary, with data from 2011, which is not the same period of the individual data, and may contain inaccuracies regarding frequent changes that occur in commercial establishments. Also, understanding the reasons why bars, restaurants, and snack bars were protagonists in relation to other establishments was not the object of this study and, therefore, it is a field of research for future studies. Finally, the degree of relationship between the adult interviewed and the adolescent at home is not known, which makes it difficult to verify the association between alcohol consumption by parents and the adoption of this behavior by the adolescent.

Although circular buffers have limitations as to the accuracy of an individual's true exposure in the urban environment, due to the high connectivity between the streets, this difference becomes smaller ${ }^{34}$, reinforced by the use of the establishments' basis in the previous study ${ }^{35}$. The results show the complexity related to alcohol consumption by adolescents, associated with the individual, family, and environmental factors. They also foster the importance of discussing policies for the regulation of alcohol consumption, which are still a major challenge in the face of economic interests. 


\section{REFERENCES}

1. World Health Organization. Global status report on alcohol and health 2018. Genebra: World Health Organization; 2018.

2. World Health Organization. Adolescents: health risks and solutions. Genebra: World Health Organization; 2018.

3. Romano M, Duailibi S, Pinsky I, Laranjeira R. Pesquisa de compra de bebidas alcoólicas por adolescentes em duas cidades do Estado de São Paulo. Rev Saúde Pública 2007; 41(4). http://dx.doi.org/10.1590/ S0034-89102007000400001

4. Pinsky I, Sanches M, Zaleski M, Laranjeira R, Caetano R. Patterns of alcohol use among Brazilian adolescents. Rev Bras Psiquiatria 2010; 32(3). http: / / dx.doi.org/10.1590/S1516-44462010005000007

5. Jorge KO, Ferreira RC, Ferreira EF, Vale MP, Kawachi I, Zarzar PM. Binge drinking and associated factors among adolescents in a city in southeastern Brazil: a longitudinal study. Cad Saúde Pública 2017; 33(2): 1-13. http://dx.doi.org/10.1590/0102-311x00183115

6. Vlahov D, Galea S. Urbanization, Urbanicity, and Health. J Urban Health 2002; 79: S1-S12. http:/ / dx.doi. org/10.1093/jurban/79.suppl_1.s1

7. Rowland B, Evans-Whipp T, Hemphill S, Leung R, Livingston M, Toumbourou JW. The density of alcohol outlets and adolescent alcohol consumption: An Australian longitudinal analysis. Health Place 2016; 37: 43-9. https:/ / doi.org/10.1016/j.healthplace.2015.11.004

8. Hearst MO, Fulkerson JA, Maldonado-Molina MM, Perry $\mathrm{CH}$, Komro KA. Who needs liquor stores when parents will do? The importance of social sources of alcohol among young urban teens. Prev Med 2007; 44(6): 471-6. http:/ / doi.org/10.1016/j.ypmed.2007.02.018

9. Laranjeira R, Hinkly D. Evaluation of alcohol outlet density and its relation with violence. Rev Saúde Pública 2002; 36(4). http://dx.doi.org/10.1590/ S0034-89102002000400011

10. De Boni R, Cruz OG, Weber E, Hasenack H, Lucatelli L, Duarte P, et al. Traffic Crashes and Alcohol Outlets in a Brazilian State Capital. Traffic Inj Prev 2013; 14(1): 86-91. http:/ / doi.org/10.1080/15389588.2012.690164

11. Azar D, White V, Coomber K, Faulkner A, Livingston $\mathrm{M}$, Chikritzhs T, et al. The association between alcohol outlet density and alcohol use among urban and regional Australian adolescents. Addiction 2016; 111(1): 65-72. https: / / doi.org/10.1111/add.13143

12. Lu S, Du S, Ren Z, Zhao J, Chambers C, Wang J, et al. Accessibility of Catering Service Venues and Adolescent Drinking in Beijing, China. Int J Environ Res Public Health 2015; 12(7): 7208-19. https: / d dx.doi. org/10.3390\%2Fijerph120707208
13. Rowland B, Toumbourou JW, Livingston M. The Association of Alcohol Outlet Density With Illegal Underage Adolescent Purchasing of Alcohol. J Adolescent Health 2015; 56(2): 146-52. http:// doi. org/10.1016/j.jadohealth.2014.08.005

14. Shih RA, Mullins L, Ewing BA, Miyashiro L, Tucker JS, Pedersen ER, et al. Associations between neighborhood alcohol availability and young adolescent alcohol use. Psychol Addict Behav 2015; 29(4): 950-9. https: / / dx.doi.org/10.1037\%2Fadb0000081

15. Pasch KE, Hearst MO, Nelson MC, Forsyth A, Lytle LA. Alcohol outlets and youth alcohol use: Exposure in suburban areas. Health Place 2009; 15(2): 642-6. https: / / dx.doi.org/10.1016\%2Fj.healthplace.2008.10.002

16. Milam AJ, Johnson SL, Furr-Holden CDM, Bradshaw CP. Alcohol Outlets and Substance Use among High Schoolers. J Community Psychol 2016; 44(7): 819-32. https: / dx.doi.org/10.1002\%2Fjcop.21802

17. Ferreira AD, César CC, Malta DC, Andrade ACS, Ramos CGC, Proietti FA, et al. Validade de estimativas obtidas por inquérito telefônico: comparação entre VIGITEL 2008 e inquérito Saúde em Beagá. Rev Bras Epidemiol 2011; 14(Supl. 1). http:/ / dx.doi.org/10.1590/ S1415-790X2011000500003

18. Andrade ACS, Peixoto SV, Friche AAL, Goston JL, César CC, Xavier CC, et al. Social context of neighborhood and socioeconomic status on leisure-time physical activity in a Brazilian urban center: The BH Health Study. Cad Saúde Pública 2015; 31(Supl. 1). http://dx.doi. org/10.1590/0102-311X00069514

19. Friche AAL, Diez-Roux AV, César CC, Xavier CC, Proietti FA, Caiaffa WT. Assessing the Psychometric and Ecometric Properties of Neighborhood Scales in Developing Countries: Saúde em Beagá Study, Belo Horizonte, Brazil, 2008-2009. J Urban Health 2013; 90(2): 246-61. https:// dx.doi. org/10.1007\%2Fs11524-012-9737-z

20. Meireles AL, Xavier CC, Andrade ACS, Friche AAL, Proietti FA, Caiaffa WT. Self-rated health in urban adults, perceptions of the physical and social environment, and reported comorbidities: The $\mathrm{BH}$ Health Study. Cad Saúde Pública 2015; 31(Supl. 1). http:/ / dx.doi.org/10.1590/0102-311X00076114

21. Célio FA, Friche AAL, Jennings MZ, Andrade ACS, Xavier CC, Proietti F, et al. Contextual characteristics associated with the perceived neighbourhood scale in a cross-sectional study in a large urban centre in Brazil. BMJ Open 2018; 8: e021445. http:// dx.doi. org/10.1136/bmjopen-2017-021445 
22. Cayo MR, Talbot TO. Positional error in automated geocoding of residential addresses. Int J Health Geogr 2003; 2(1): 10. https:/ / doi.org/10.1186/1476-072X-2-10

23. Alcohol and Public Policy Group. Alcohol: No Ordinary Commodity - a summary of the second edition. Addiction 2010; 105(5): 769-79. https:// doi. org/10.1111/j.1360-0443.2010.02945.x

24. Arnauts I, Oliveira MLF. Padrão de consumo do álcool por jovens vítimas de trauma e usuários de álcool. Rev Min Enferm 2012; 16(3): 410-8.

25. Carlini ELA, Noto AR, Sanchez ZVDM, Carlini CMA, Locatelli DP, Abeid LR, et al. VI Levantamento Nacional sobre o Consumo de Drogas Psicotrópicas entre Estudantes do Ensino Fundamental e Médio das Redes Pública e Privada de Ensino nas 27 Capitais Brasileiras - 2010. São Paulo: Centro Brasileiro de Informações sobre Drogas Psicotrópicas (CEBRID); Universidade Federal de São Paulo (UNIFESP); Secretaria Nacional de Políticas sobre Drogas (SENAD); Brasília: SENAD; 2010.

26. Malta DC, Mascarenhas MDM, Porto DL, Duarte EA, Sardinha LM, Barreto SM, et al. Prevalência do consumo de álcool e drogas entre adolescentes: análise dos dados da Pesquisa Nacional de Saúde Escolar. Rev Bras Epidemiol 2011; 14(Supl. 1). http:// dx.doi. org/10.1590/S1415-790X2011000500014

27. Locatelli D, Sanchez Z, Opaleye E, Carlini C, Noto A. Socioeconomic influences on alcohol use patterns among private school students in São Paulo. Rev Bras Psiquiatria 2012; 34(2): 193-200. http:// dx.doi. org/10.1590/S1516-44462012000200012

28. Drumond EF, Hang-Costa TA, Souza HNF. Presença de álcool em adolescentes vítimas de homicídios em Belo Horizonte 2005-2009. Rev Min Enferm 2014; 18(2). http:/ / www.dx.doi.org/10.5935/1415-2762.20140021

29. Sanchez ZM, Santos MG, Pereira AP, Nappo AS, Carlini EA, Carlini CM, et al. Childhood Alcohol Use May Predict Adolescent Binge Drinking: A Multivariate Analysis among Adolescents in Brazil. J Pediatr 2013; 163(2): 363-8. https: / / doi.org/10.1016/j. jpeds.2013.01.029
30. Milam AJ, Furr-Holden CDM, Bradshaw CP, Webster DW, Cooley-Strickland MC, Leaf PJ. Alcohol Environment, Perceived Safety, and Exposure to Alcohol, Tobacco, and Other Drugs in Early Adolescence. J Community Psychol 2013; 41(7): 86783. https: / dx.doi.org/10.1002\%2Fjcop. 21579

31. Simões C, Matos MG, Batista-Foguet J. Consumo de substâncias na adolescência: um modelo explicativo. Psic Saúde \& Doenças 2006; 7(2).

32. Barrenechea MA, González CE, López JMQ, González AB, Cortés FJM, Saiz AC. Prevalencia del consumo de tabaco en adolescentes. Influencia del entorno familiar. An Pediatr 2007; 66(4): 357-66. https: / / doi. org $/ 10.1157 / 13101240$

33. McCord ES, Ratcliffe JH. A Micro-Spatial Analysis of the Demographic and Criminogenic Environment of Drug Markets in Philadelphia. Austl \& NZ J Crim 2007; 40(1): 43-63. https: / / doi.org/10.1375\%2Facri.40.1.43

34. Oliver LN, Schuurman N, Hall AW. Comparing circular and network buffers to examine the influence of land use on walking for leisure and errands. Int $J$ Health Geogr 2007; 6: 41. https: / doi.org/10.1186/1476-072X-6-41

35. Matozinhos FP, Gomes CS, Andrade AC, Mendes LL, Pessoa MC, Friche AA, et al. Neighbourhood environments and obesity among adults: A multilevel analysis of an urban Brazilian context. Prev Med Rep 2015; 2: 337-41. https: / / dx.doi.org/10.1016\%2Fj.pmedr.2015.04.019

\section{Received on: 10/07/2019 \\ Revised on: 01/28/2020 \\ Accepted on: 01/30/2020}

Authors' contributions: B. B. C. Carvalho and A. C. S. Andrade contributed to the literature review, data analysis, and writing. R. G. Andrade, L. L. Mendes, and J. G. V. Melendez collaborated in revising the final version of the article; C. C. Xavier and F. A. Proietti helped in the development of the project and review of the final version of the article. W. T. Caiaffa contributed to the development of the project, study design, literature review, data analysis, and writing of the article. 